\title{
Filipino Farmers' Awareness and Adaptation to Climate Change
}

\author{
Genalyn Panganiban Lualhati ${ }^{1}$, Shiela R. Lumbaga ${ }^{1}$, Nazarene Carlo M. Pagaspas ${ }^{1}$ \& \\ Ma. Fatima N. Quimio ${ }^{1}$ \\ ${ }^{1}$ College of Teacher Education, Batangas State University JPLPC-Malvar, Philippines \\ Correspondence: Genalyn Panganiban Lualhati, College of Teacher Education, Batangas State University JPLPC- \\ Malvar, Batangas Province, 4232, Philippines. E-mail: genpanganiban_0301@ yahoo.com
}

Received: May 9, 2018; Accepted: May 21, 2018; Published: June 29, 2018

\begin{abstract}
In the Philippines, agriculture plays a vital role because this sector can contribute a lot in the development of the economy. The value of documenting the agriculture growth annually and the problems encountered is being done by the government particularly, the Department of Agriculture (DA) to come up with interventions or programs to support the Filipino farmers, both in rural and urban areas. Hence, this study focused on determining the farmers' awareness on climate change and their adaptation strategies in one municipality in Batangas Province. By employing mixed method through self-made questionnaire and focus group discussion, this study revealed that respondents are highly aware on climate change and the best strategy to use in adapting to climate change was conservation agriculture. The study offered recommendations that different authorities can employ to strengthen the farmer's awareness and adaptation on climate change.
\end{abstract}

Keywords: Awareness, Farmers, Adaptation, Climate Change, Agriculture

\section{Introduction}

In the year 1997, the Agriculture and Fisheries Modernization Act (AFMA) was passed by the Senate. The AFMA is a comprehensive blueprint for agriculture modernization and rural development. This aims to transform the rural economy through the introduction of modern technology, increasing availability of rural financing, increasing investments in agricultural infrastructure, improving the links between farmers and markets, both domestic and international, and others. Through this law, it is believed that this will be the answer to the country's agricultural crisis.

Twenty years had passed after the passage of the law; yet, the agriculture sector has been performing below expectations and potential most especially in the rural areas as revealed by the Senate Economic Planning Office (SEPO) Policy Brief. Small farmers in the rural areas are experiencing adversities and it is charged to the adverse effects of climate change to their land and crops.

Climate change has become a globally unequivocal issue which has been frequently addressed by a variety of groups including media, scientists, environmentalists, politicians and educational practitioners. Significant climatic changes in the world were already evident from the observations of, for instance, rising global average temperature, surging average sea level, the changes of frequency or intensity of extreme weather events (i.e., tropical cyclones, heat waves, heavy precipitation, cold/hot days), and etc. (Intergovernmental Panel on Climate Change [IPCC], 2007).

In addition, IPCC (2007) also concluded that most of the observed increase in global average temperature since the mid-20th century was 'due to the escalation of greenhouse gas (GHG) concentrations through anthropogenic activities such as burning fossil fuels and plastics. The Intergovernmental Panel for Climate Change Fourth Assessment Report (IPCC Working Group I, 2007) concludes that there is stronger evidence that human activities are already affecting the world's climate and these bad practices result to different challenges especially to the fishermen and farmers.

These challenges were met because drastic changes of climate can degrade the quality of the soil. Bishaw et. al (2010), stated that climate change is manifested in recurrent drought, floods, and famine that have threatened millions of people and livestock in recent decades. Further, Weiner et al. (2013) found out that in environmentally stressed communities, farmers met challenges in planting and harvesting crops. Subsistence farming practices are the main livelihood for most people living in this kind of community, which is characterized by degraded soils, small farm sizes, and low agriculture outputs. 
According to a recent study, the social and ecological systems in the Philippines are considered "very vulnerable" to climate change as a result of overfishing, weak social and economic indices, high dependence on fisheries, high rates of poverty within the agricultural sector, population growth, and poor governance (Mamauag et al., 2013). Vulnerability of agriculture and agriculture communities to climate change is a function of exposure, sensitivity to change, and adaptive capacity (Daw et al., 2009), which vary considerably within and between countries and populations (Cinner et al., 2012). Generally, poorer and less empowered countries and individuals are more vulnerable to climate impacts (Daw et al., 2009).

In order to survive, farmers have thought of simple methods to adapt to changes in climate. The challenge now is to adapt within very short periods of time to potentially extreme impacts and new risks and opportunities. This will be achieved through a combination of managerial, infrastructural and technical measures. Hence, these methods must be comprehensibly taught to the farmers for them to be aware and skilled.

According to United Nations Educational, Scientific and Cultural Organization [UNESCO] (2011), the education for mitigation helps people in realizing their unsustainable consumption patterns and lifestyles that contribute to gas emissions and climate change problem. Education for adaptation prepares farmers and all people for uncertain future with both risks and opportunities to increase their adaptive capacity. On the other hand, local small farmers are supported by the Local Government Units (LGUs) as mandated by Climate Change Act of 2009 (RA 9729). It states that LGU are responsible for planning and implementing their own Local Climate Change Action Plans, while collaborating with other LGUs, coordinating vulnerability assessments with private entities, and building capacity for local adaptation planning, implementation and monitoring.

Since Philippines is an agricultural country having agriculture as a primary source of national income and in line with the country's goal of determining interventions or programs to help the farmers achieve sustainability, this study was conducted to determine the awareness and adaptation strategies on climate change of selected farmers in the Local Government Unit of Malvar, with an end view of formulating extension services activities to strengthen the farmers' awareness and adaptation on climate change. Through the conduct of this study, the researchers may have baseline idea on what could be the additional educational supports that can be extended to the farmers in order to sustain their farms and promote agricultural development in the locality. The result of the study could be an answer to the pressing need of sustainable and accessible environmental education, not only to the minority groups, but also to the youth.

\subsection{Objectives of the Study}

This descriptive study concentrated on the awareness and adaptation strategies on climate change of selected farmers in the Local Government Unit of Malvar, with an end view of formulating extension service activities to strengthen the farmer's awareness and adaptation on climate change. It also determined the extent of how the farmers utilized different adaptation strategies on climate change as to agroforestry, conservational agriculture and agricultural credit sources.

\section{Methodology}

The researchers utilized the mixed method of research through the self-constructed questionnaire and focus group discussion (FGD). According to Creswell (2011), mixed method research focuses on collecting, analysing, and mixing both quantitative and qualitative data in a single study or series of studies. Its central premise is that the use of quantitative and qualitative approaches, in combination, provides a better understanding of research problems than either approach alone.

Due to the nature and scope of this study, the respondents of this research were selected farmers of 15 barangays in the Municipality of Malvar, Batangas. The total number of farmers, which was 332, was obtained from the records of the Municipality of Malvar. Through the use of a sampling technique, the researchers used 181 farmers as their respondents. The researchers believed that greater number will give them extensive data that could provide reliable facts to analyse in accordance with the problems posted in this study.

The study made used a self-made questionnaire. The items of the questionnaire were based on the readings done by the researchers. Questions are also based on some review of related studies. This is consisted of two parts. These parts are based upon the specific problem of the research study. The first part determines the respondents' level of awareness on climate change. The second part comprises the extent of utilization of different adaptation strategies that may be described along with the following: agroforestry, conservational agriculture and agricultural credit sources.

In determining the respondents' level of awareness on climate change, the following mean ranges with their corresponding interpretations were used. 


\begin{tabular}{lll}
\hline Numerical Value & Mean Ranges & Interpretation \\
\hline 4 & $3.25-4.00$ & Strongly Agree/Highly Aware \\
3 & $2.50-3.24$ & Agree/Aware \\
2 & $1.75-2.49$ & Disagree/Slightly Aware \\
1 & $1.00-1.74$ & Strongly Disagree/Not Aware \\
\hline
\end{tabular}

The respondents assessed the hazard mitigation practices of the Local Government Unit of Malvar. To be able to interpret the computed mean, the following mean ranges with their corresponding interpretations were used.

\begin{tabular}{lll}
\hline Numerical Value & Mean Ranges & Interpretation \\
4 & $3.51-4.00$ & Often/Highly Utilized \\
3 & $2.51-3.50$ & Sometimes/Utilized \\
2 & $1.51-2.50$ & Seldom/Slightly Utilized \\
1 & $1.00-1.50$ & Never/Not Utilized \\
\hline
\end{tabular}

The researchers used mean to gather data subjected to the statistical treatment of their study.

After the title and the statement of the problem have been finalized for the construction of the questionnaire, the researchers looked for needed information and started organizing the proposal. The researchers sought the approval of the authorities concern to conduct the investigation. Upon the approval, the researchers personally distribute the questionnaire. They informed the concerned individuals on the purpose of the study. The researchers explained briefly the purpose of the study and instructions on how to answer the questionnaire.

\section{Results and Discussions}

This chapter covers the presentation, analysis and interpretation of the quantitative data gathered in the investigation. The discussions of the findings are patterned in a manner that coincides with the organization of the problems posed in the study.

Table 1. Respondents' Level of Awareness on Climate Change

\begin{tabular}{|c|c|c|}
\hline Item Statements & Mean & Verbal Interpretation \\
\hline As a farmer, I know that ... & & \\
\hline $\begin{array}{l}\text { 1. climate change refers to the rise in average surface temperatures on } \\
\text { Earth. }\end{array}$ & 3.94 & Strongly Agree \\
\hline $\begin{array}{l}\text { 2. pollution from industry is viewed as the main cause of climate change } \\
\text { and may affect other areas like agricultural areas. }\end{array}$ & 3.59 & Strongly Agree \\
\hline $\begin{array}{l}\text { 3. disasters like flashflood and soil erosion are the effects of climate } \\
\text { change in agricultural production. }\end{array}$ & 3.80 & Strongly Agree \\
\hline $\begin{array}{l}\text { 4. proper energy consumption may reduce the effects of climate change } \\
\text { in agricultural production. }\end{array}$ & 2.92 & Agree \\
\hline $\begin{array}{l}\text { 5. the potential future effects of climate change includes longer periods of } \\
\text { drought in some areas and increased heat waves. }\end{array}$ & 3.76 & Strongly Agree \\
\hline $\begin{array}{l}\text { 6. frequent changes in precipitation patterns and extreme weather events } \\
\text { increase the average temperature of the Earth's surface. }\end{array}$ & 3.67 & Strongly Agree \\
\hline $\begin{array}{l}\text { 7. climate change is caused by different irresponsible human activities } \\
\text { like using aerosols, burning plastics, and using fossil fuels }\end{array}$ & 3.79 & Strongly Agree \\
\hline $\begin{array}{l}\text { 8. La Nina and El Nino and other weather disturbances increase stress on } \\
\text { forest and agricultural land }\end{array}$ & 3.76 & Strongly Agree \\
\hline $\begin{array}{l}\text { 9. rising temperature and carbon dioxide reduces concentration of protein } \\
\text { and most essential minerals causing low nutritional value of most food crops }\end{array}$ & 3.54 & Strongly Agree \\
\hline $\begin{array}{l}\text { 10. low agricultural productivity due to decreased water availability is one } \\
\text { of the results of climate change }\end{array}$ & 2.40 & Slightly Agree \\
\hline Composite Mean & 3.52 & Highly Aware \\
\hline
\end{tabular}

In determining the respondents' level of awareness on climate change, the result indicates that farmers were aware regarding this matter as shown at Table 1. This is justified by the study of Institute of Philippine Culture (2011) about the social impacts of tropical storm Ondoy and typhoon Pepeng due to global warming. It was found out 
that $85 \%$ of the respondents have greater awareness on the dangers of typhoon, flooding and possible mitigation measures following the mentioned typhoons.

Table 2.1 Respondents' Extent of Utilization of Adaptation Strategies to Climate Change in Terms of Agroforestry

\begin{tabular}{lll}
\hline Item Statements & Mean & Verbal Interpretation \\
\hline As a Farmer, I... & & Often \\
$\begin{array}{l}\text { 1. promote natural regeneration of desirable plant/tree species as } \\
\text { an affordable and easily managed option for the conservation and } \\
\text { increase of beneficial trees }\end{array}$ & & \\
$\begin{array}{l}\text { 2. enrich fodder reserves by planting trees in the woodlands }, \\
\text { pastures and waterways. }\end{array}$ & Seldom & \\
$\begin{array}{l}\text { 3. plant trees along roadsides, rural areas and ornamental sites to } \\
\text { offer shade, improve micro-climate, and provide woods, fruits and } \\
\text { other products. }\end{array}$ & Sometimes \\
$\begin{array}{l}\text { 4. plant fruit trees in settlements around homestead, water points } \\
\text { and areas with irrigation for the generation of income. }\end{array}$ & 3.35 & Sometimes \\
$\begin{array}{l}\text { 5. install windbreaks to conserve soil and moisture improving } \\
\text { micro-climate. }\end{array}$ & 1.18 & Never \\
\hline Composite Mean & $\mathbf{2 . 7 6}$ & Utilized \\
\hline
\end{tabular}

Overall, the farmers utilized Agro-forestry as their adaptation strategy to climate change. This obtained a composite mean of 2.76. This implies that farmers considered tree covering and buffering as an approach to adapt to climate change. According to Torquebiau (2013), sustainability attributes of agroforestry are strong assets for climate change adaptation. Today's climate change context confirms the potential of agroforestry.

Table 2.2 Respondents' Extent of Utilization of Adaptation Strategies to Climate Change in Terms of Conservational Agriculture

\begin{tabular}{|c|c|c|}
\hline Item Statements & Mean & Verbal Interpretation \\
\hline As a Farmer, I... & & \\
\hline $\begin{array}{l}\text { 1. practice proper plowing farmlands, and leaving crop residue in the } \\
\text { field to improve soil fertility and water conservation }\end{array}$ & 3.95 & Often \\
\hline $\begin{array}{l}\text { 2. observe zero tillage that helps maintain and improve the } \\
\text { environment. }\end{array}$ & 1.85 & Seldom \\
\hline $\begin{array}{l}\text { 3. practice collecting the residues from crops and yields to use it as } \\
\text { fertilizers to soil rather than using commercial fertilizers. }\end{array}$ & 3.64 & Often \\
\hline 4. use permanent organic soil cover as fertilizer to soil. & 3.76 & Often \\
\hline avoid soil compaction through aeration to reduce water run-off. & 2.84 & Sometimes \\
\hline Composite Mean & 3.21 & Utilized \\
\hline
\end{tabular}

This result signifies that the farmers considered conservation agriculture practices can contribute to making agricultural systems more resilient to climate change. As supported by CCMT (2011), conservation agriculture is as an approach to farming that seeks to increase food security, alleviate poverty, conserve biodiversity and safeguard ecosystem services. In addition, conservation agriculture or zero tillage also helps to maintain and improve the environment. 
Table 2.3 Respondents' Extent of Utilization of Adaptation Strategies to Climate Change in Terms of Credit Sources

\begin{tabular}{lll}
\hline Item Statements & Mean & Verbal Interpretation \\
\hline As a Farmer, I... & & \\
$\begin{array}{l}\text { 1. borrow money from LandBank of the Philippines (LandBank) to } \\
\text { sustain my livelihood opportunities }\end{array}$ & 3.07 & Sometimes \\
$\begin{array}{l}\text { 2. get financial assistance from rural banks within the Municipality } \\
\text { who offer low interest and less requirements }\end{array}$ & 3.06 & Sometimes \\
$\begin{array}{l}\text { 3. avail the Local government's financial and machinery assistance to } \\
\text { augment other expenses and enhance my crop production }\end{array}$ & Sometimes \\
$\begin{array}{l}\text { l. borrow money from relatives, friends, co-farmers to buy } \\
\text { crops/plants, fertilizers and other needed resources to support my existing } \\
\text { farming. }\end{array}$ & & \\
$\begin{array}{l}\text { 5. Loan money from cooperatives (i.e. Sororo Ibaba Development } \\
\text { Cooperative) to enhance our agricultural activities. }\end{array}$ & 2.52 & Sometimes \\
\hline Composite Mean & $\mathbf{2 . 8 9}$ & Utilized \\
\hline
\end{tabular}

Overall, it is worthy to note that farmers utilized credit sources as their adaptation strategy to climate change. This implies that farmers file for a loan to sustain their farmland. This finding suggests that the LGU of Malvar may review their agricultural provisions to better assist the small farmers. As supported by the study of Tulagan et al. (2013), in their findings that the loan assistance extended for agricultural production in the municipality is not enough to be able to meet the financial needs of the farmers because of too small portion of fund allotted to it. Also, acquiring such loans is not easy because of many requirements needed for them to be able to avail it.

Table 3. Best Strategy to Utilize to Adapt to Climate Change

\begin{tabular}{lll}
\hline Strategies & Mean & Verbal Interpretation \\
\hline Agro - Forestry & 2.76 & Utilized \\
Conservational Agriculture & 3.21 & Utilized \\
Agricultural Credit Sources & 2.89 & Utilized \\
\hline Composite Mean & $\mathbf{2 . 9 5}$ & Utilized \\
\hline
\end{tabular}

As a result, it is revealed that the best strategy small farmers employed were Conservation Agriculture (CA). As supported by Kabirigi et al. (2015), it is revealed that in Rwanda, Kenya's situation, CA has a good potential for climate change adaptation in both high and low rainfall areas of the region.

On the other hand, the researchers employed FGDs among the small farmers to obtain other perspective concerning the best strategy to utilize to adapt to climate change. Careful analyses of their responses to interview and group discussions led the researchers to come up with the following themes:

\section{a. Share Valuable Farming Tips}

Decades of intensified heat and wind, less rainfall, and unpredictable weather served as their basis in adapting to climate change. Farmers in Malvar are taking advantage of an important resource, which are the Experienced Farmers. Long years in the job and extensive observation gave them simple ideas on how to mitigate the risk brought by climate change. Farming techniques were shared and taught to other farmers to help them adapt to climate change.

One of the farmers said that, "Sa tagal ko nang nagsasaka, alam ko na kung paano didiskarte sa pabago-bagong panahon ..."

\section{b. Be Prepared for Disasters}

A farmer from San Isidro said that, “... pinakamabisang paraan ay ang pagiging listo at handa.”

With the reality of climate change already rearing its ugly head, at-risk regions need to be prepared for the inevitable disasters on the horizon. Early warning systems and shelters are crucial, but people also need to be informed about what to do in case of an emergency. Localities also need to be prepared for the aftermath, ensuring that people will have access to safe drinkable water. Being prepared also means smarter development. "Our exposure to extreme events is growing and this trend needs to be addressed through better land use and more 
resilient infrastructure as we seek to cope with population growth and rapid urbanization," according to the NDMRRC.

\section{c. Loan Availment to Non-formal Credit Sources}

Majority of the farmers reiterated that, “... mahirap mangutang sa bangko, kaya nanghihiram na lang kami sa kamag-anak, kaibigan o kung saan madali, o nagsasangla ng jeep."

Farmers' preferences and conveniences in credit facilitation were not well served which could lead them to take alternatives like borrowing capital in informal lenders and friends. This is an alarming situation because recovering from loans is hard to achieve due to higher interest rates. Therefore, it implies that there is a need for providing new/innovative financing schemes that address the problems of the farmers who lack in collateral, and minimize long processing of documents and other requirements.

In one way or another, government funding, if properly allocated and use for the agriculture interventions/programs will somehow lessen the possibility of availing loans to informal lenders. With this, it is worthy to mention that the government and banks and cooperatives as formal source of credit are encouraged to review their policy and programs related to agriculture. Through this, farmers will be motivated to better make use of formal credit and decline from the offer of informal lenders. The low reliance on informal lenders means avoidance of higher interest rates which in turn can increase the farmers' efficiency and monthly family income.

Table 6. Proposed Extension Services Activities to Strengthen Farmers' Awareness and Adaptation to Climate Change

\begin{tabular}{|c|c|c|c|c|}
\hline Objectives & Strategies/ Activities & Person/s Involved & $\begin{array}{l}\text { Target } \\
\text { Date }\end{array}$ & $\begin{array}{l}\text { Expected Outcome/ } \\
\text { Output }\end{array}$ \\
\hline $\begin{array}{l}\text { To strengthen } \\
\text { farmers' knowledge } \\
\text { on Global Warming } \\
\text { and other } \\
\text { environmental } \\
\text { crises/issues }\end{array}$ & $\begin{array}{l}\text { Awareness Seminar on Environmental } \\
\text { Issues- This activity will be participated } \\
\text { in by small farmers to better enlighten } \\
\text { them on the effects of these issues to } \\
\text { farming. } \\
\text { Design and Production of Flyers, } \\
\text { Leaflets, brochures and the likes- This } \\
\text { Education Information Materials (EIC) } \\
\text { will be distributed after the seminar. } \\
\text { EIC are useful to further educate the } \\
\text { farmers on climate change and other } \\
\text { relevant issues. }\end{array}$ & $\begin{array}{l}\text { LGU of Malvar, Executive } \\
\text { Director, } \\
\text { Dean of Colleges, Associate } \\
\text { Dean, Head and Coordinators } \\
\text { of Extension Services, Faculty } \\
\text { Members, Student } \\
\text { Organizations }\end{array}$ & September 2017 & $\begin{array}{l}\text { Small farmers of Malvar } \\
\text { are highly aware of } \\
\text { different environmental } \\
\text { issues. }\end{array}$ \\
\hline $\begin{array}{l}\text { To give assistance to } \\
\text { farmers in terms of } \\
\text { facilities/ equipment }\end{array}$ & $\begin{array}{l}\text { Project Development Study- The three } \\
\text { departments of the campus may } \\
\text { collaborate with one another in } \\
\text { designing and developing windbreaks- } \\
\text { This activity aims to design and develop } \\
\text { a windbreak that can be donated to the } \\
\text { farmers of Malvar. Expenses for the } \\
\text { installation will be also covered by the } \\
\text { campus. }\end{array}$ & $\begin{array}{l}\text { LGU of Malvar, Executive } \\
\text { Director, } \\
\text { Dean of Colleges, Associate } \\
\text { Deans, Head and } \\
\text { Coordinators of Extension } \\
\text { Services, Faculty Members, } \\
\text { Student Organizations; }\end{array}$ & $\begin{array}{l}\text { January } 2018 \text { to } \\
\text { December } 2019\end{array}$ & $\begin{array}{l}\text { Installation of windbreaks } \\
\text { in different farmland of } \\
\text { Malvar }\end{array}$ \\
\hline $\begin{array}{l}\text { To provide financial } \\
\text { assistance to the } \\
\text { farmers to sustain } \\
\text { their farmland }\end{array}$ & $\begin{array}{l}\text { Loan Availment Program for the } \\
\text { Farmers- The University, in partnership } \\
\text { with the LGU, can provide financial } \\
\text { assistance to the farmers with low } \\
\text { interest rates. The university can } \\
\text { establish a MOA to the LGU to realize } \\
\text { this goal. }\end{array}$ & $\begin{array}{l}\text { LGU of Malvar, Executive } \\
\text { Director, } \\
\text { Dean of Colleges, Associate } \\
\text { Deans, Head and } \\
\text { Coordinators of Extension } \\
\text { Services, Faculty Members, }\end{array}$ & $\begin{array}{l}\text { Year Round, } \\
\text { depending on } \\
\text { the needs }\end{array}$ & $\begin{array}{l}\text { Farmers are able to } \\
\text { sustain their livelihood } \\
\text { through the money lend to } \\
\text { them by the University. }\end{array}$ \\
\hline
\end{tabular}

\section{Conclusions and Recommendations}

This research explored the awareness and adaptation strategies on climate change of selected farmers in the Local Government Unit of Malvar, with an end view of formulating extension services activities to strengthen the farmers' 
awareness and adaptation on climate change. The study involved 181 farmers in 15 barangays of Malvar, Batangas. Questionnaires and focus group discussions were used to gather the needed data. Self-constructed questionnaire was personally administered and retrieved by the researchers. The answers were tallied, tabulated and analyzed through the use of statistical tools such as frequency and percentage, and weighted mean.

The findings of the study afforded the researchers in drawing various suggested activities on climate change of selected farmers in the Local Government Unit of Malvar. Provision of budget and installation of windbreaks may be considered by the LGU of Malvar, through the Office of Agriculture, to conserve soil and its moisture. The LGU of Malvar may encourage the small farmers of different barangays to observe zero tillage to help maintain and improve the environment through orientation, seminar, or general assembly. There is a need for providing new/innovative financing schemes that address the problems of the farmers who lack in collateral, and minimize long processing of documents and other requirements. Different financial institutions as well as the LGU of Malvar may consider taking this into consideration. The LGU of Malvar may orient and train the farmers of other approaches/strategies to adapt to climate change. The proposed extension service activities by the researchers may be implemented, monitored, evaluated, and reviewed to ensure its efficiency on strengthen the farmers' awareness and adaptation on climate change. Since this study deals with numerous concerns, a similar or a follow-up study may be conducted using other variables.

\section{References}

Agriculture, Natural Resources and the Environment. (2006). Manila. Philippine Institute for Development Studies (PDIS), Discussion Paper Series No. 2000-2006.

Cristina, D. (2007). Key Indicators for Public Expenditures in Agriculture, Natural Resources and Environment.

David, C., \& Inocencio, A. (2007). Key Indicators for Public Expenditure in global warming and climate change.

Harmer et al. (2014). Climate Change Response at the Farm Level: A Review of Farmers' Awareness and Adaptation Strategies in Developing Countries.

Henderson, K. J. (2013). Small Business Owners. Retrieved April 28, 2018, from http://2014.stidays.archiv.zsi.at/wp-content/uploads/2014/02/CPDAVID.pdf

Henderson, K. J. (2013). The Average Income of Small Business Owners.

Institute of Philippine Culture. (2010). Rapid Assessment of the Social Impacts of Tropical Storm Ondoy and Pepeng. Unpublished Thesis, Quezon City: Institute of Philippine Culture.

Kabirigi, M., et al. (2015). Applicability of conservation agriculture for climate change adaptation in Rwanda's situation.

Primo, C. D. C. (2013). Climate change impact on water resources: The Philippines as a case study: National Institute of Geological Sciences, University of the Philippines - Diliman, Metro Manila.

Tulagan, et al. (2013). Self- sufficiency Performance of the Municipality of Malvar: Unpublished Thesis. Batangas State University JPLPC Campus.

\section{Copyrights}

Copyright for this article is retained by the author(s), with first publication rights granted to the journal.

This is an open-access article distributed under the terms and conditions of the Creative Commons Attribution license (http://creativecommons.org/licenses/by/4.0/). 